\title{
(Re-)De-Commodification in Academic Knowledge Distribution?
}

\author{
Michael Nentwich
}

\begin{abstract}
This paper argues that the system of formal scholarly publication is entering its third phase of evolution. This phase has not yet taken full shape, but is characterised by a strong de-commodified core with only niches for commercial publishers - in contrast to phase II which was the age of increasing commodification. The main reasons for this development are economic, functional and ideational.The current economic crisis of academic publishing is driving academia to alternative models. From a functional perspective, the advent of E-publishing makes it possible that academia will take over most of what is currently done by the commercial publishers. Finally, the last decade has seen an increasing awareness of the research community that its products should not be treated as a commodity, but should instead be freely available to the whole community.
\end{abstract}

Keywords: commodification, information \& communication technologies, scholarly publication

The output of research can be viewed from three perspectives. Beyond any doubt, the primary function of research is to contribute to scholarship on which future research can be based. Second, the output converted into publications plays an important role in the academic career of individual researchers. The socalled record often forms the basis of assessments for hiring or tenure. From a final point of view, research output in the form of publications can also be regarded as a commodity. This will be looked at in depth here.
There are considerable differences among the disciplines: mainly in the science, technology and medicine (STM) disciplines, where research is often very close to application and particularly valuable. But also in the humanities, where publications are regarded also as trade objects, a view with unintended consequences.

Many academics readily assign the copyrights to the publishers because they do not view their articles as valuable commodities. Others tend to do the same because they want to get published 
in prestigious journals and therefore obey the 'rules of the game' as developed over the last decades. As a result, the publishers gain the right to sell the publications under their own (commercially oriented) terms. This is often in contrast with both the interests of the individual researcher and of the scientific community at large, in particular the interests of the universities which need to devote ever larger shares of their library budgets to buying back their faculty's material previously given to the publishers.

Atkinson (2000) has framed the issue in terms of an ideological difference between the main intermediaries in the scholarly information exchange process: libraries and publishers. He argues that the long-term evolution of information services will depend finally upon the ultimately prevailing intermediary ideology. In his words, the fundamental ideological question is "whether specialized academic information should be understood as a commodity, intended primarily for (and judged in each case by the extent to which it succeeds in generating) revenue - or whether access to scholarly information is a social good that must be freely available (Atkinson, 2000: 62)."

This paper is structured as follows: first, I distinguish three phases of scholarly communication to set the scene for a description of the current developments. I describe the crisis of the existing system in phase II and then systematise the various initiatives to change the status quo with a view to shaping phase III. Against this background, I assess whether the initiatives are doomed or whether we have to expect either a split system - partly commodified and partly de-commodified - or a uniformly de-commodified one in the medium run.

\section{Three Phases of Scholarly Communication}

Seen from the viewpoint of the relationship between scholarly publications and the market, we are able to distinguish three phases of scholarly communication: the original state of greatest possible distance, the system of commodification and finally, the present partial counter-movement. Note that these phases are certainly not clear- cut in the sense that one may give an exact point in time when one phase is over and the other started. For our analytical purposes here, it is nevertheless very useful to contrast these three phases with a view to highlight their main characteristics.

The first phase is characterised by the advent of the early academic journals in the $17^{\text {th }}$ century which institutionalised and generalised the earlier (preGutenberg) system of written scholarly correspondence among individual scholars and exchange of manuscripts. The first journals published were by Académie Française in Paris and the Royal Society of London for the Promotion of Natural Knowledge in 1665. These publications were still heavily influenced by the previous form of "letters". The important point to note here is that it was scholarly associations (academies and societies) of the state (the King) which supported this new system. As it is still the custom today, national scholarly societies and academies exchanged their respective series. Scholarly publications were not yet treated as "commodities", but heavily subsidised by the scholarly institutions until the 1960s. Walker (1998) reports that although scientific societies published most science 
journals, some were published by other non-profit institutions, such as universities, museums and governments while commercial publishers were generally not attracted to the field because there was too little potential for profit. The same holds true for the university presses, which started to print scholarly books only shortly after the invention of printing from movable type in the late $15^{\text {th }}$ century. Oxford University Press, for instance, started printing already in 1478. The presses' explicit goal was not primarily to sell books, but to advance scholarship through making the research results available to fellow scholars.

The second phase rests on an increasing role of the "market" and so-called trade-publishers since the beginning of the last century. Elsevier Science, for instance, has been in the business for more than 100 years. The time of these new actors came in the 1960s (Walker, 1998) and they proved to be very efficient in turning scholarly output into commodities. This development did not take place at equal speed and similar success in all academic disciplines. In general, however, large parts of academic publishing are in the hands of the private sector today. The noteworthy characteristic of the present situation is the fact that scholarly authors normally give away their to-be-published works for free, or almost free, to the commercial publishers which, in turn, sell their final products back to the universities and their libraries at increasingly high prices. This has led to the so-called "serial crisis" or "journal crisis" (i.e. ever higher prices while library budgets went down) with regard to mainly journals in the STM sector, which stretches to other disciplines and the humanities book market in particular.
Consequently, at the beginning of the $21^{\text {st }}$ century, it seems that the second phase is giving way to a third phase. It is not clear yet what shape it will take, but it features, at least partially, what we might call de-commodification or, with regard to the first phase, re-de-commodification since it might reinstate the original, uncommodified situation. Information and communication technologies (ICT) have brought about new opportunities, in particular electronic publishing in the form of E-journals, E-pre-print servers (self-archiving) and self-publishing. Epublishing potentially improves the economic situation of not-for- profit journal publishers and opens up the possibility that the academic community reappropriates the publishing business.

On the one hand, libraries try to pool their resources and purchasing power in consortia and thus stay within the present paradigm. On the other hand, academics, scholarly associations and libraries set up free E-print-servers and open archives as well as non-commercial E-journals and other free knowledge resources in the WWW. A parallel infrastructure seems to emancipate itself from strict commercial considerations, facilitating various forms of not-forprofit knowledge circulation. Some of them appear to be similar to those preceding the advent of strong commercial interests in the academic publishing market. Others are quite different from the original system, due to the new opportunities provided by current ICT (see below).

\section{The Crisis of Phase II}

The crisis in the scholarly publication system (called the 'serial crisis') "has 
been well-known for almost two decades" (Whisler \& Rosenblatt, 1997). Increased prices of journals and books lead to cancellations of subscriptions and reduced orders, which lead to higher prices because less subscribers pay less while the production costs stay the same. This, again, leads to cancellations and higher prices (Okerson, 1997; Pew Higher Education Roundtable, 1998; Frisch, 1996: 362 ff.). Another source of this vicious circle is the increased focus of commercial publishers on shareholder value. " $(\mathrm{T})$ he partnership between... academia and commerce is now breaking down" (Owen, 2000: 2). At the same time, library budgets are under pressure. In Germany, the funding of university libraries increased only marginally (nominal 1,3\% from 1991-97), but the prices of journals went up $27 \%$ in the humanities and social sciences and even $77 \%$ in the natural sciences. In the US, the average price of a journal increased by $169 \%$ from 1987 to 1997 , three times more than the inflation rate. All libraries organised in the Association of Research Libraries (ARL) had to pay $124 \%$ more for $7 \%$ less journals in 1997. In the same year, Elsevier made a profit of 365 million EUR with a turnover of 910 million EUR (Sietmann, 1999: 216; cf. also Bär, 1999; Okerson, 1997).

Atkinson formulates the dilemma in terms of agent-client relationships and argues that the primary clientele of publishers are their owners (often shareholders). "When it comes to making decisions, publishers will inevitably, understandably, and justifiably make those decisions that are in the best interest of their primary clientele." (Atkinson, 2000: 63) He rightly points at the possibility of a severe aggravation of what we have observed as the traditional serial crisis through information technology which greatly enhances the control of access to information: "If it is in the primary client's best interest for the publisher to use that control to restrict access to needed information as much as possible, in order to make such information scarce and to drive up its price, then that is exactly what will happen".

Thatcher (1996: 201) speaks of only a partial failure of the market (to provide the services necessary for scholarly communication) since (at least some) science journals (still?) sell well and do not rely solely on the academic demand. The market fails in particular for nonscience: in the humanities, books cannot be sold in high enough numbers to make profits (e.g. Wasserman, 1998); the same is true for most social sciences. But even in entomology, a rather small biological discipline, "the cost of subscription- financed commercial publication was contributing heavily to the serials crisis" (Walker, 1998). Thatcher's differentiation overlooks, however, that both science and non-science books and journals are in crisis: science because of high prices, humanities/social sciences because of too few sales. There is, however, another danger involved. Whisler \& Rosenblatt (1997: 5) describe what they call the "crowding out effect": STM journals would eventually crowd out other, lesser-used journals if their prices increase more than those of other serials and monographs and if library budgets increase less than serial prices go up. At the end of the day, scholars may publish in "write-only journals" (Denning, 1996), i.e. journals they do not subscribe, nor do their institutions and libraries. 
It is important to note that the crisis is not only a journals crisis, but also a book crisis. In the humanities, in particular, and some social sciences, the potential readership of specialised books is all but sufficient to sustain their production. Bennett (1994: 244) observes that the "core business of the university press - that of publishing scholarly monographs - is becoming economically impossible while, simultaneously, the presses' core group of authors - faculty - increasingly rely on commercial publishers and on self directed Internet publishing ventures to meet the most pressing needs of scholarly communication."

This means that near-comprehensive access to the products of academic knowledge production is no longer guaranteed in the sense that raising prices make it less and less certain that a particular item can be found in any one academic library. Document delivery and online full text databases are only partially solving the problem as they make it easier to get remote access if the local repository is not able to deliver, but costs are again a problem. The commercial exploitation of academic knowledge by commercial publishers seems, however, to have reached a watershed. Increasing numbers of academics no longer acquiesce this erosion of the foundations of academic communication.

One arena of the 'battle' is intellectual property rights issues. As "the means by which we manage the dual identity of information as a private commodity to be bought and sold and as public good to be freely shared" (Bennett, 1996: 187) copyright is a pivotal issue for scholarly communication. At times, university teachers have difficulty using their own articles as course material (Bennett \&
Matheson, 1992: B1), even under the "fair use" regime. The Pew Higher Education Roundtable (1998: 4) manifesto holds that the constraints to the flow of scholarly information result "not just from prohibitive pricing but from the restrictions that commercial publishers seek to impose on the kind of use an individual faculty member can make of his or her own published work."

This is not the place to go into the details of copyright issues involved here; in particular, because this would involve assessing the differences between the U.S. and the European copyright regimes. The difficulties and problems, however, did not diminish with the advent of E-publishing, quite to the contrary.

\section{The Developments in Phase III}

Given, on the one hand, the financial crisis of academic libraries coupled with restrictive copyright management, while on the other, the new opportunities of E-publishing, various initiatives have emerged over recent years to change the dissatisfactory situation. A general motto of these initiatives might be: "The free and uninhibited exchange of academic information - efficient and at fair prices - is the pre-condition of all science." (Grötschel \& Lügger, 1996: 9) In addition, Rohe claims to observe an increasing demand for a non-profit publishing model using the new technology and submits: "Conditions are ripe for scholars to take control of scholarly publishing." (1998: 4)

In this spirit, there are various calls for action and initiatives in the (mainly) US higher education ("librarians") scene and beyond (see Okerson, 1997). These 
initiatives have been sponsored by a variety of organisations as well as various individual or groups of universities and libraries, both inside and outside the US, both national and international. ${ }^{1}$ Most of these initiatives mainly aim at topdown solutions, i.e. solutions supported by associations and consortia which can be interpreted to be aiming to replace the present with an (at least partly) decommodified system. The new system would rest on E-publishing and university or associational publishing, as opposed to trade publishing.

\section{Self-publishing - Public Self-archiving}

In addition to the above top-down solutions, various initiatives exploit the new electronic opportunities bottom-up. Self-publishing comes in a variety of forms: individuals setting up download pages, research institutes offering electronic working-paper series, students running low-cost E-journals etc. Franks (1993: part I) calls individual publishing the "vanity press model" and Ullman (1996) comments: "Today, the amateur has returned to the world of research publication." There are, however, also more organised models of the "new" publishing: E-journals, meta-archives and E-pre-print archives. Most importantly, there are "faculty and research entrepreneurs" (Thatcher, 1996: 202; Bennett, 1996: 191) or "trailblazers" (Okerson, 1991b: 15) who initiate, develop and often run these free services in favour of the research community.

E-journals

Given the low costs of running an E-journal, it comes as no surprise that this has become a quite common bottom-up route for establishing an alternative selfpublishing market for academic publications. The (online) Directory of Scholarly Electronic Journals (first edition) reports that in December 2000, there were 5436 E-journals whereas the seventh edition (1997) of its predecessor counted only 1465 . While it is true that many of these additional E-journals are commercial E-journals which parallel their traditional paper counter-parts, there are many genuine electronic-only series, mostly offered for free or at very moderate fees because they are supported by the enthusiasm of individuals and their affiliations. One illustrative example is reported by Sietmann (1999: 218 ) with a journal's editors and editorial staff leaving its publisher due to enormous price increases (several $100 \%$ ) and successfully founding a new journal, mainly distributed as an E-journal (Evolutionary Ecology Research).

It is not the place here to assess in detail the merits of E-journals and their place vis-à-vis the traditional journals. Note however, that E-journals have already acquired an important place in many disciplines and are, for instance, recognised in the British research assessment exercise since 1996. Many of them are sustainable academic endeavours, publishing already for many years with much success (with considerable differences between the various academic specialities).

Meta Archives

Another route are electronic archives, which make departmental or associational E-publications (mainly working paper series) centrally accessible and 
searchable. This helps to overcome the intrinsic weakness of the self-publishing model that access to the various electronic sources is unorganised, unfiltered and hence difficult. Such meta archives exist in many disciplines, e.g. in economics (RePEc) ${ }^{2}$ or in European integration research (ERPA).

Recently, the Open Archives Initiative (OAi) succeeded in setting a common standard for the meta-data of papers included in these archives. This is expected to be implemented gradually by many archives. The aim is to make all archives inter-operable world-wide and to promote their establishment by making the necessary software available for free.

\section{E-pre-print Servers}

A third route is the establishment of discipline-specific electronic pre-print servers. The idea is that papers are "uploaded" individually to a central server before they are published in a traditional or E-journal. Bennett (1996: 190) observes:

"that in today's increasingly digital environment, by the time a research paper is ready for publication, it has already been widely read... The commonplace observation is that published journals are now little more than the archives of science, while most of the vital work of scholarly communication is carried elsewhere. Of course there is much variation from discipline to discipline in this disassociation of validation from conventional publication."

Many such servers have followed the first well-known and very busy physics server at Los Alamos (ArXiv), for instance in the cognitive sciences (CogPrint) and in the philosophy of science (PhilSciArchive). Harnad (n.y.) is sure that ArXiv "is the herald of what will happen in all disciplines sooner or later" (see Hibbitts, 1996a; 1996b).

That the formal exchange of specialised scholarly information "can thrive outside of traditional publishing channels" (Atkinson, 2000: 59) has a revolutionary touch since widespread electronic distribution of pre-prints seems bound to destroy high-cost journals (Odlyzko, 1994: 45). Perhaps the most prominent advocate of this route is the brain scientist Stevan Harnad (1993; 1997), with his well-known Subversive Proposal extensively discussed in Okerson and O'Donnell (1995). In a later paper, Harnad summarises his proposal - which is already practiced in the CogPrint archive - as follows:
All authors should continue to entrust their work to the paper journals of their choice. But if, in addition, they were to publicly archive their pre-refereeing pre-prints and then their post-referee- ing reprints on-line on their home serv- ers, for free for all, then the de facto prac- tices of the reader community would take care of the rest...; library serial can- cellations, the collapse of the paper cardhouse, publisher perestroika, and a free for all, e-only serial corpus financed by author-end page charges would soon follow suit. (Harnad, 1998: 128)

As pointed out by many, the system of public E-pre-print archiving could easily be combined with a journal system in the sense that the archives are for registering priority claims and making information available as quickly as possible, while the new journal system would consist of refereeing and certifying. Taubes (1996: 768) refers to the idea that submitting to the journal would then only mean that the author submits the reference number of the manuscript in the archives. The journal could then 
"freeze the article" by changing the password disallowing the author to change that manuscript with a view to assuring that a paper that has been accepted for publication is indeed the same one readers have been downloading (see Atkinson, 2000: 67). A less far-reaching proposal would redefine the copyright transfer to publishers. Bennett et al. propose that, when the author/university agreed to give the copyright to the publisher, they would explicitly give nonprofit organizations like universities and libraries the right to copy the articles in response to specific requests for them. The core of their proposal is that "faculty members would not transfer the copyrights of articles... to any publisher unwilling to accept that condition" (Bennett \& Matheson, 1992).

The "Subversive Proposal" and similar ideas are, of course, very much disputed. For instance, Harnad proposes author- end page charges to finance the system (e.g. Harnad, 1997: 6; Walker, 1998). Tomlins (1998: 147) notes that this "reproduces what has long been traditional practice in the humanities, a model as now beset by precisely those pressures that he thinks it can subvert". Note also the extensive debate between Harnad and Varian in (Harnad et al., 2000), followed up in much "skywriting" (to use Harnad's own term) in electronic forums like the September98Forum on these issues and the current online debate in "Nature". There is certainly no space to list all the arguments here. Although both agree in principle that online self-archiving is a way to solve the current crisis, they disagree on the reasoning why this is so.

One strand of opposition to the selfpublishing models focuses on the cost issue, arguing that the costs of publication are not eliminated, but only shifted, often hidden in other university budgets and perhaps even increasing overall as it is unlikely that the work will be done either as well or as cheaply as it would be by professional publishers (Day, 1998: 2) Day notes the danger that the researchers who would otherwise be doing research and teaching or their support staff enabling those crucial activities become both engaged in the work of publishing to the detriment of the time available for teaching and research. While there is certainly some truth in this observation, it is not really an argument against self-publishing since, already now, most work involved in publishing has to be done by the scientific community itself.

E-print servers have the potential either to replace the traditional scholarly publication system altogether or to organise the pre-refereeing phase very differently. In the latter case, quality control would still be entrusted in the journal system, while in the former case it would be incorporated. Their main advantages over the phase II system are their universal accessibility, speed and low cost. How such systems would be financed, is still an open question, but it seems that the relatively low costs could be borne by the professional associations.

\section{Central, Comprehensive Digital Archives} and Open Source

While the E-pre-print archives only include pre-prints and the meta archives mainly departmental working papers, a number of initiatives go one step further (respectively take another route) aiming 
at archives comprehending not only "grey", but also published literature. The most prominent examples of this are PubMed Central for the life sciences managed by the US National Library of Medicine (NLM). A famous new initiative by a number of scientists, including Nobel laureates (Roberts et al., 2001) aims to create "public, electronic archives of the scientific literature, containing complete copies of all published scientific papers".

In the beginning, at least, the commercial publishers of STM literature are quite reluctant to give free access to their products via such services. Therefore only a few journals are already available through PubMed Central. The number is steadily growing, but some think archives such as these will never cover an area completely because of the financial interests involved.

\section{Open Source}

Phase III de-commodification is not only driven by primarily economic reasons, but also inspired by another movement which has its roots in software development. Raymond (1999) describes the 'bazaar method' of managing large software projects according to the open source model. It rests on collaboration over the Internet while the source code remains in the public domain and cannot, in principle, be sold. "Science, after all, is ultimately an Open Source enterprise." (DiBona et al., 1999: 1) DiBona et $a l$. argue that the sources have to be shared: the hypothesis, the test conditions, and the results. They argue that it is one function of academic publishing to put the scientific knowledge in the public domain because the open shar- ing of scientific results facilitates discovery minimises duplication of effort. DiBona et al. hold that programming according to the open source model shares with science an emphasis on reputation: "Scientists aren't supposed to hoard profits from their inventions, they are supposed to publish and share their inventions for all to benefit from." (DiBona et al., 1999: 7)

Although much of the academic enterprise is not profit- oriented, some is. For the not-for-profit sectors, the open source model may be a model for the future. There are already projects like OpenBook, OpenTheory and the like. The Open eBook Consortium tries to promote an open standard for e-books to avoid the present splitting due to commercial considerations (Adobe PDF, Microsoft Reader). In its OpenCourse-Ware project, MIT plans to make all teaching material available over the Internet free of charge (see Hartmann, 2001).

Gräbe (1998) brings in another aspect: if scholarly publishing moves to the electronic world, then the software and the standards of knowledge representation become an important issue. He warns that it may well happen that academia will not be able to pay for accessing the digital knowledge units, if the software were not open-source-like or if the rights are not kept within the academic realm.

\section{A New Role for University Presses and Academic Libraries}

"We are a not-for-profit organisation, but also a not-for-loss organisation." (Martin Blume, editor in chief of the American Physical Society, interviewed by Albrecht, 2001) 
The crisis described above might not only be solved via self-publishing, but also by those academic institutions which are traditionally in the business of publishing and archiving, namely university presses and libraries. Three reasons can be listed:

First, while (groups of) scholars engaging in the business of self-publishing in whatever form are tackling something relatively new for them, the presses are professionals and might be at the core of cyberscience publishing because "(t)he geniuses of this new technology have created the new vocabulary... but their brainchild lacks depth. It is a thousand miles broad but only a quarter-inch deep, and we can offer depth."(Zeigler, 1997: 42) Thatcher (1996: 202) suggests an important role for university presses instead of amateurish "faculty and research entrepreneurs" doing it themselves. He argues that presses have valuable and cheap skills to offer and that the time of academics is often treated as a free good, but it is not. Presses' special skills are not only in the technical domain, but in organising the certification and filtering of scholarship (which remains the realm of academics).

Second, the financial crisis is an incentive. As Okerson (1991a: 3) notes, it is hardly surprising that a vision of university-based publishing captures the imagination of parts of academe since “(a)bout $90 \%$ of formal academic publications migrate outside the academy before returning home as repurchased monographs and serials." Thatcher demonstrates that the dissociation of supply and demand, i.e. the insufficient demand for scholarly publications in the marketplace, was "the very basis of the rationale for university-based publishing in the first place, not a new phenomenon just affecting us today"(1996: 200). Most university presses, however, publish principally in the humanities (Walker, 1995: 38). Consequently, if the presses should play a more prominent or even dominant role in academic publishing, they would also need to capture the science market.

Third, there is a necessity of academic institutions to become (again) publishers themselves in many areas since they could not find a commercial partner, e.g. for the publication of scientific software, databases and the like (Grötschel \& Lügger, 1996). Hence, it is not only financial reasons which make academics and their institution initiate moves away from commercial publishers, but also the (perceived) impossibility to market particular categories of academic results (because there is no market, the costs are too high). In this respect, E-publishing might offer "many new opportunities for university presses [because] (u)niversities have human and computing resources that would offset the factor of market dominance to some degree" (Walker, 1995: 40).

Like the self-publishing route discussed above, another potential central role for university presses in phase III could lead to a nearly de-commodified system of scholarly exchange. Chodorow argues that there are three possible ways to solve the serial crisis: consortial purchase and licensing of information resources; a new pricing system for information; and exploring schemes to change the information market itself. Only the third way is, in his view, promising: "...the creation of a new market for scholarly information that preserves the low prices necessary to the successful maintenance of the modern academic 
enterprise." (Chodorow, 1998: 7)

Chodorow describes the new market as separate from the 'edutainment' market now developing, and as not needing the middlemen - the commercial publishers - in the academic market. He argues that those features would enable scholars and universities to distribute information among themselves "in a system affected by costs instead of profits"(1998: 7). Whisler and Rosenblatt suggest a scenario for universities in which they themselves would invest capital resources more heavily in university-based information flows and new forms of scholarly publication, as well as place increased market pressures on the commercial sector. They argue that if universities "were to make strategic capital and staffing investments in university presses during the short term, the presses could be more likely to make a successful and rapid transition to electronic publication" (Whisler \& Rosenblatt, 1997: 22). At the same time, intensive university efforts (i.e. investments) to recover STM and business publishing from the private sector should be made to reduce the crowding out of university press publications by for profit publishers which could also be accompanied by libraries placing strong market pressures on commercial publishers through cancellation of journals whose prices rise faster than the average rates for scholarly journals in general. Whisler and Rosenblatt predict that the investments could be recovered over time through reductions in capital investments in library buildings. If their vision came true, the university itself would encompass most of the information flow in scholarly communication through its networked capability. "That information having commodity value outside of the academy could be sold in the marketplace, and the revenues used as a subsidy to the system itself." (Whisler \& Rosenblatt, 1997: 22)

There is, however, still a long way to go since "(m)any universities have committed a major error in trying to force their university presses to become selfsupporting. This policy has resulted in the presses identifying increasingly with - and adopting the values of - commercial publishers." (Atkinson, 1996: 261) Bennett and Matheson (1992) envisage that universities might funnel more money into the university presses if the money now spent in their libraries could be redirected to university-published journals. As Okerson reported, this train has been set in motion already at the beginning of the last decade. At least in the US, university-based publishing was receiving significant attention. In 1991 she noted that " $(t)$ he mechanisms are almost in place; the community is energetic and eager; the need is urgent" (Okerson, 1991a: 6).

Given their quandary between trade publishers and demanding faculty, academic libraries are among the most active promoters of phase III. Apart from their activist agenda- setting role, libraries contribute two things: first, they can cooperate among themselves to gain greater market power vis-à-vis the commercial publishers, and second, they may themselves enter the domain of publishing. Such examples are the Scholarly publishing and academic resource coalition (SPARC), High Wire Press and Cooperative Online Resource Catalog (CORC) initiatives (Owen, 2000: 3). Libraries have also a traditional role to play with regard to providing access to the published material. "However, the 
job of organizing, coding, linking, updating, licensing, and maintaining that wide range of material takes on new significance." (Wittenberg, 1998: 2) The example given is CIAO, a repository and resource portal for researchers in the field of international affairs research.

\section{A New Role for Academic Associations}

Many argue that it should be the primary task of academic associations to organise the de-commodified phase III scholarly communication system. Some of the initiatives have been mentioned already when discussing the electronic archives and pre-print servers; here we shall add some proposals and initiatives directly engaging the professional associations.

Getz has proposed that scholarly associations might ally themselves with the working-paper sites, give the service an official status and invest in the features with a view to make it more robust and useful. "Although freebie... services are useful, an enhanced... service for a fee (or as part of membership) might be much better." (Getz, 1997: 9) If professional bodies and associations will again become more actively involved in publishing, the flow of information might be more directly and quickly delivered form host institution to requester, author or researcher (Johnston, 1998: 12). A noncommercial system of refereed scholarly communication can be combined with peer review. Morton favours a centralised system on the shoulders of scholarly associations who would sponsor a 'super site' providing "sanctioned stature - a surety that only bona fide scholarly work would be resident" (Morton, 1997: 4). He proposes that copyright remains with the author or the employing institution and concludes that in his model the process of communication would predominate over the issues of product and ownership embodied in the present commercial model.

Another important issue at stake is quality control. The associations pool all resources necessary to secure quality in phase III. As Atkinson puts it: "It should be the function of academic information services to ensure that national - or preferably international - peer review structures are in place." (Atkinson, 1993: 210) Various models have been proposed, some of them involving the cooperation with traditional journal structures, be they run by commercial publishers or not, others setting in place completely new structures. For instance, Atkinson (2000: 60) sees "an unprecedented opportunity to reconfigure information services" and argues that "the academy needs to use disintermediation as a tool to re-appropriate responsibility for formal scholarly communication that in the past has been the exclusive domain of scholarly publishers." His own proposal is called 'The Designated Channel' for each discipline. All scholarly work would go into this channel. This means that "the item does indeed add substantial knowledge" and that academia will guarantee its access over time. There will be "normative meta data" informing about currently perceived importance of an item in the database and will be indexed based on controlled vocabulary. Usetracking, i.e. access data, will add further information about the paper's merits. The library's task would be to create a synopsis, stipulating what is new or unique in the publication which should add up to cumulative meta data forming a sort of encyclopaedia. Politically, 
these channels would separate information access from the institutions. The bibliographic value is "one-stop shopping", e.g. on the basis of the OAi standard. Atkinson's proposal is based on his earlier thoughts about a "control zone" into which all important scholarly material would go, namely "a single, virtual, distributed, international digital library" which he describes as a library which has (conceptual, virtual) boundaries and which defines its service operationally on the basis of the opposition between what is inside and outside those boundaries. He claims that the academic community would have to consider the creation of a control zone understood as something that is technically and conceptually separate from the open zone (Atkinson, 1996: 254 ).

Whether or not the scholarly associations will actually support these new systems depends on at least two issues: the relationship to commercial publishers and financial issues. If a scholarly association is already linked with (or financially supported) conventional journals that are published by commercial publishers, withdrawing from such links and going entirely the E-way poses serious dilemmas for them since the commercial publishers in many cases hold proprietary rights to the journals. Conceivably, the publishers might just go their own way if associations sever their links, and would end up competing with the new de-commodified (associational) journals. This dilemma may inhibit many associations from going this route. ${ }^{3}$ Associations, however, may be in a quite powerful position, for instance if journal subscriptions are linked to membership in the association. In this case, the commercial publisher would lose almost all of its subscribers at once while the competing new journal would take up most of them.

As to financing such systems, Walker (1998) proposes a scheme of charges paid by the authors for re-prints in a society's journal whereby part of the revenue would finance eventually putting all papers online for free access by users. Morton (1997: 4) proposes "annual institutional site-gateway fees" to be based on the institutional budget or on the number of researchers who potentially could place publications at the site. Ginsparg (1996: 7) envisages for those research communities with a relatively small number of authors and a much larger number of readers a model "wherein the institutions that support the research assert copyright privilege, assume the role of publishers, and disseminate material produced in-house for a fee to those institutions that only consume it." He admits that this would upset proponents of free electronic access to all publicly supported research material but claims that it would be a logical system, in which the real risk-takers (the institutions that support research by way of investment in salary and equipment) are able to profit from and protect the products of that investment.

\section{De-commodification?}

Phase III is, so far, a time of change. It is not clear yet what shape exactly it will take, but it features, at least partially, what we might call de-commodification or rede-commodification since it might reinstate the original, un-commodified situation. Most probably, there will be a mixed system - partly commodified, 
partly de-commodified. Although some hopes of a completely new scholarly publication system are not yet fulfilled (and may never be), I hold that in the medium run, free access archives like ArXiv and the like may succeed in most disciplines. The main driving force is that, with the help of ICT, the core business of academic publishing, in the sense of formal scholarly communication, can be done without commercial publishers.

\section{The Case for De-commodification}

This argument rests on the answer to the following question: What does publishing involve and who can render the services? If it turns out that the traditional system is neither adding evident value nor in a significantly better position to render the necessary services, and if, at the same time, the alternative system is much cheaper, the latter might ultimately replace the former.

If we look at the various functions to be performed, we can distinguish between four groups. First, those tasks which, already in phase II, are done by the scholarly community as a whole anyway. This includes editing, i.e. "running" the journal. Managing editorial rules and corresponding with authors, referees etc. is typically done by an academic anyway (now increasingly via E-mail, see Appel, 1996). Scholarly quality control, i.e. finding out whether the submitted article is new, valuable etc., is always done by academics. Reputation or branding is certainly a service provided by publishers, as Rohe (1998: 2) argues: "A well-known publisher's name is similar to a brand name." According to Atkinson, "We do not really pay for what is in [the publishers] publications; what we pay for is rather that what is in their publications acquires a certain status and attracts a certain attention by virtue of its location in those publications." (Atkinson, 2000: 64 , emph. in orig.) No doubt, scholarly associations or universities could be, as they are already in some areas, the new brand names for scholarly publications. In principle, there is no need for commercial brands which are mainly targeted at increasing revenues, less at increasing reputation for scholars. The tricky question involved here is, however, whether setting up a parallel infrastructure, run by academia itself, would have the power to attract enough academic authors to break even, i.e. to detract authors and consequently reputation from the commercial system.

One proposed route is that universities do not allow their faculty to submit to commercial publishers any more. This could be combined (and in fact is already in some areas) with libraries not buying these journals any longer (also because they are too expensive anyway) which would make them less accessible and hence less attractive. A more liberal alternative would be to make the alternative system more attractive. This could be done for instance by formally upgrading the status of the alternative vis-à-vis the traditional journals when it comes to research assessments. Furthermore, attractiveness could be enhanced by high-quality and all-encompassing search-engines which cannot be provided by commercial publishers due to their competitive policies. We can only speculate whether the scholarly system and, indeed, the academics themselves are flexible enough to gradually switch to the new system. In any case, there are already a number of powerful proto- 
types which shed some light on the possible future (see above).

The second group of functions is increasingly being performed by the author, not by the publisher. For instance, typesetting, formatting, page-composition, layout, tagging, including the HTML or, later on, XML coding, is done to an ever increasing degree by the author with the help of auto-formatting editor software. ${ }^{4}$ As to proof-reading, there will be no differences to the status quo: the author him- or herself is proofreading. In any case, professionalism in the academic publishing process, in general, and with a view to typesetting and copy-editing, would have to be upheld. But these are functions which could also be supervised by people within academia (e.g. in the university presses or scholarly associations).

A third group of tasks in academic publishing are typically outsourced. These can as well be done by phase II/ III non- profit publishers, such as university presses and/or the university or research institutions itself. This includes language editing which, in most cases, is already done by the scholars themselves; copyediting, i.e. the part of quality control which relates to formal necessities, such as a complete and coherent bibliography, etc., is either included in the typesetting/tagging or still outsourced as done now with most books. Furthermore, ever more sophisticated software is spreading among researchers and doing much of the job of a copyeditor in advance and automatically. For instance, new bibliographic software makes sure that the reference list is accurate and comprehensive, as well as in the desired format.

A fourth set of tasks will be increas- ingly handed over to specialised software and could be simply or nearly superfluous in phase III. For instance linking, i.e. fitting the articles into a web of knowledge, making them retrievable etc. could be done by the publishers (Hunter, 1998: 2). However, there are already first examples of linking tools which do the job automatically on the basis of input by authors and editors. Printing will be done locally, by the reader or the library. Distribution is, in the E-world, done via the Internet. No packaging or shipping is necessary. Financial transactions, if at all necessary, are being automated. Marketing is trickier, but how much marketing is actually done by scientific publishers? Is it not mainly the authors who promote their books in conferences, by referencing in journal articles and refereeing books for journals? In an E-world, marketing could be turned into an information service, eventually via centralised access points with E-mail subscription services and/or accessible by knowbots (personalised knowledge robots). MacKie-Mason and Riveros (1997: 2) may be right to claim that " $(\mathrm{g})$ ood scholars are good at research, not at finding readers" but finding readers could be organised in a more refined and probably more efficient way. By contrast, Mueller holds that "the global niche of scholars who do [a particular speciality] can be expected to spread the word among themselves." (2000: 4)

Furthermore, copyright management would be almost superfluous in a decommodified scholarly world. Fisher (1993), for instance, opposes the present copyright management system to two alternative systems which he calls 'author-managed', i.e. one where the authors retain their copyrights and conse- 
quently have to handle all related business, and 'institution-managed', where the authors' institutions (university presses) do the job. Fisher argues that, if a journal's policy was to permit any and all photocopying, the prices would go up enormously and the subscription rates down to one per journal. Furthermore, 'secondary publishers' (indexing services etc.) will have the costly burden to have individual relationships with each author or institution instead of a few publishers, which would turn their business to expensive. If the purpose of copyrights would not be to protect commercial interests of either authors nor publishers, but solely to protect authors from intellectual theft, then authors could retain their copyright and everybody could make copies (electronic or print) for free as long as not abusing the content.

Finally, the publishers claim to bear the financial, entrepreneurial risk of publishing. Given the high prices, however, the small editions (of books) and the often considerable print subsidies required for a book to be actually printed (borne by the authors, their institutions or research funds), this risk does not seem to be important. What is more important is that the risk can be taken by academia as well (for example the university presses). The advent of E-publishing also helps as it is much cheaper to make PDF files from a book than printing it. Consequently, the financial risk is actually diminishing.

Looking at this list of arguments, the result is that there is no particular need for commercial publishers in the system of scholarly communication, or in the words of Okerson: "Crudely put, it seems that the publisher is superfluous." (1995: Intro). This view is, however, not undis- puted. The main counter-argument is that authors are not in the best position to take over the publishing business (e.g. MacKie-Mason et al., 1997: 2; Walker, 1995: 39; Jensen, 1998: 3; Rowland, 1994; Day, 1998: 2). But as already mentioned, universities or scholarly associations could easily invest in hiring professionals, and still save money, in phase III.

Most authors, therefore, maintain that the phase II system will be replaced by a new set up. With regard to the book market, Mueller (2000: 4) argues that the decision of whether or not to publish no longer depends on the prognosis of the number of sold copies. He claims that the publisher has a reputation to protect, but incurs no particular costs since editorial costs are pushed to the author, the cost of approval by peer review is borne collectively by institutions, production and distribution costs are not incurred until an actual sale, and advertising and marketing can be ignored. Many leading scholars are convinced that "(e)ither a collaborative solution will be reached, with paper publishers retooling themselves to perform those of their services that will still be required in purely electronic publishing, or scholars will simply bolt, and create their own purely electronic publishing systems." (Harnad, 1993: 4; see also Atkinson, 1993: 210; Hibbitts, 1996b: 2.16)

\section{Niches for Sustained Commodification?}

Commercial publishers will not leave academic publishing without trying to reverse the trend. Although they are wealthy and well-established institutions, the development of a free-ware opposition culture and the technological developments (all outlined above) 
suggest that their role will be significantly smaller in the medium term, already. At the same time, a number of niches may persist where commercial publishers possess specific know-how that cannot easily be paralleled in academia. I shall outline a few such potential niches.

Even if most academic papers would be accessible for free via the Internet, commercial journals could play a role. Along with other journal editors, Bloom for instance, argues that "quality information worthy of appreciation requires more effort than most scientists could muster, even if able." (1998) One possibility is that they would specialise in completely new services, such as providing added value in comparison to the web databases. The reason for buying and reading journals would be less that they contain original papers but rather that the editorial boards provide the readers with analysis by putting new papers in context: editorials and comments sorting information may become the hearth of a journal (Graetzel von Graetz, 2000). Delamothe and Smith (2001) go even one step further by suggesting that if journals cannot add value then they will die, and then add: "But if reading them can be a pleasure not a chore then they can survive." They see seven roles for journals: (1) selecting research that is important to their audiences; (2) presenting it in as exciting and as relevant a way as possible; (3) digesting and synthesising research which means in his view to turn it from information to knowledge; (4) educating readers, particularly on subjects that are new to them but which will change their lives; (5) setting the agenda and encouraging debate within the community; (6) prompting unfamiliar but deep thoughts; and (7) entertaining the customer. This last point, popularising academic output, could be particularly attractive to commercial publishers, and is traditionally put aside by academics. In addition, the added value could also consist of quality reprinting, important research in a more fancy way than perhaps downloads from the Internet, printed with a standard black and white printer.

Apart from very special journals of a new type, commercial publishers may also further develop their proprietary search-engines, which specialise effectively in particular academic subjects. Both the user of such a service, and those E-journals and E-series wanting to be in such a database would have to pay.

Another area for potential continued commercial involvement in scholarly publication is the production of interactive student text books and E-monographs. Easier access, visual processing, enhanced intellectual content, electronic linking and provision of moving images are all laborious tasks which require special skills and time and might hence be provided by publishers. The same is true for multimedia publications (Odlyzko, 1994: 46; similar Götze, 1996: 70). Hence, the new role for commercial publishers might be that of a very specialised service provider.

While it is impossible to know in advance which niches actually will persist, these examples suggest that one should expect such niches for commercial publishers, even if phase III takes place in the form sketched above.

\section{Conclusions: Phase III in the Making}

Phase III of the evolution of the system of formal scholarly publication has not 
yet taken full shape, but will - in contrast to phase II which was the age of increasing commodification - most likely be characterised by a strong de-commodified core with some niches for commercial publishers. The core will probably be a publishing system run by scholarly associations where scholars upload their E-"prints" on central servers ("E-preprints"). These papers may undergo subsequent quality control, either by being submitted to the editorial boards of Ejournals or by some other innovative rating process organised by scholarly associations. Although the shift from phase II to phase III is gradual and evolutionary, as soon as it will be completed, the outcome will be fundamentally different from the status quo ante. If our analysis holds, it will be more than the search for a new balance of power between the major players (commercial publishers, university presses, libraries, universities, scholarly associations), but instead a considerable upgrading of the role of all players except the commercial publishers.

We have mainly focused on functional reasons for this development, both economic - the system crisis of phase II and how the academic community is about to react to this challenge and the new technical opportunities of ICT which have already taken over many of the functions performed by the private sector. In addition, we have presented ideational developments which herald phase III the growing conviction that almost free access to scholarly work on the Internet is a good idea, and the open source perspective which could slowly develop normative power and de-legitimise phase II arrangements.

Important additions to such a lens are, for sure, institutionalist concerns. Issues of path-dependency and lower costs should not be underestimated. Commercial publishers as well-established actors of phase II should not simply be expected to vanish, and they are certainly trying to develop strategies with a view to avoid marginalisation. For instance, document delivery services, on-demand publishing and various archives are already well under way. In addition, we need to take into account that even the various actors within academia have different interests. Corporate research universities play a different tune than under-funded state universities so that institutional competition could be a significant impediment. In addition disciplinary differences, in particular the varying proximity of the research to the market in general, is an important factor.

Finally, re-appropriation requires "deep-seated cultural adjustments within the academy" (Atkinson, 2000: 64). However, there are already new institutions and new ways of going beyond for-profit publishing, hence stability seems challenged and new pathways are on offer.

\section{Acknowledgements}

This paper is part of a wider research project on the impact of ICT on science and research, at ITA, Vienna ${ }^{5}$, partly financed by the Austrian Research Fund (FWF). I am indebted to R. Werle, L. Suarez-Villa and G. Falkner for their helpful and challenging comments on earlier drafts of this paper. 


\section{Notes}

1 These initiatives include the following: the initiatives of the Andrew W. Mellon foundation (e.g. Cummings et al., 1992); the CETUS project (CSU-SUNY-CUNY Joint Committee, 1997); the Scholar's Forum by the library of Caltech (Buck et al. 1999; on previous Caltech and similar initiatives see Guernsey 1998; Rowen et al. 2000); the Big12Plus Libraries Consortium (1998); the model university policy regarding faculty publication in scientific and technical scholarly journals (TRLN, 1993); the German Commission for purchase of the German Library Institute (Sietmann, 1999:216; cf. also Bär, 1999); very active in the field are the Association of Research Libraries and the Association of American Universities, with e.g. the ARL serial prices project 1989; the Consortium for electronic publishing (CEP); the International Scholars Academic Network (IScAN) 1997; the Electronic Scholarly Publishing (ESP) proposal 1996; the AAU committee on digital networks and intellectual property; the Joint AAU/ARL task forces on intellectual property rights in an electronic environment (AAU Task Forces 1994); and, well known, the Pew Higher Education Roundtable (1998).

2 The Internet addresses (URLs) of the various online projects and institutions mentioned can all be found at http://www. oeaw.ac.at/ita/cyberlinks.htm, an interactive link database constantly updated.

3 I am grateful to L. Suarez-Villa for suggesting this argument.

4 Fisher notes that in an early, MIT-Press-run E-journal, the managing editor also did the tagging and "typesetting". The same is true for many other E-journals and E-series.

5 A more complete and constantly updated bibliography including all URLs if available can be found via the project homepage at http://www.oeaw.ac.at/ita/ cyberscience.htm.

\section{References}

AAU Task Forces

1994 Acquisition and Distribution of Foreign Language and Area Studies Materials; A National Strategy for Managing Scientific and Technological Information; Intellectual Property Rights in an Electronic Environment; report, comm. by: Association of American Universities and Association of Research Libraries, May, Washington: ARL.

Albrecht, J.

2001 "Das Netz für freie Forschung” (Net for free research). Die Zeit 19, 3.5.2001: 44.

Appel, A. W.

1996 "How to Edit a Journal by E-mail". Journal of Scholarly Publishing 27, 2: 82-99.

Atkinson, R.

1993 "Networks, hypertext, and academic information services: some longerrange implications". College \& Research Libraries 54, 3: 199-215.

1996 "Library Functions, Scholarly Communication, and the Foundation of the Digital Library: Laying Claim to the Control Zone”. The Library Quarterly 66, 3: 239-265.

2000 "A rationale for the redesign of scholarly information exchange". Library Resources and Technical Services 44, 2: 59-69.

Bär, S.

1999 "Das große Würgen” (The great choking). Laborjournal, 4.

Bennett, $\mathrm{S}$.

1994 "Repositioning University Presses in Scholarly Communication”. Journal of Scholarly Publishing 25, July: 243-248.

1996 "Re-engineering Scholarly communication: Thoughts Addressed to Authors". Journal of Scholarly Publishing 27, July: 185-196.

Bennett, S. \& Matheson, N.

1992 "Scholarly Articles:Valuable Commodities for Universities". Chronicle of Higher Education, 27 May 1992: B1-B3. 
Big12Plus Libraries Consortium

1998 Scholarly Communication and the Need for Collective Action: A Statement by the Chief Academic Officers of the Big 12; Accessed on: 01-16 2001. http:/ /www.big12plus.org/pressreleases / scholar.htm.

Bloom, F. E.

1998 "The Rightness of Copyright”. Science 281, 5382: 1459-1460.

Buck, A. M., Flagan, R. C. \& Coles, B.

1999 Scholars' Forum: A New Model For Scholarly Communication; Accessed on: 01-16 2001. http://library.caltech. edu/publications/scholarsforum/.

Chodorow, S.

1998 "The Faculty, the University, and Intellectual Property". Journal of Electronic Publishing 3, 3.

CSU-SUNY-CUNY Joint Committee

1997 The Academic Library in the Information Age: Changing Roles, comm. by: Consortium for Educational Technology for University Systems CETUS. http://www.cetus.org/acad_lib.pdf.

Cummings, A. M., Witte, M. L., Bowen, W.

G., Lazarus, L. O. \& Ekman, R. H.

1992 University Libraries and Scholarly Communication; report, comm. by: The Andrew W. Mellon Foundation Association of Research Libraries. http: / / www.lib.virginia.edu/mellon/mellon. html.

Day, C.

1998 "Digital Alternatives: Solving the Problem or Shifting the Costs?". Journal of Electronic Publishing 4, 1.

Delamothe, T. \& Smith, R.

2001 "PubMed Central: creating an Aladdin's cave of ideas". British Medical Journal online, 322: 1-2.

Denning, P. J.

1996 "Journals' End? or Electronic publishing Plan a Must". Computing Research News, September.

DiBona, C., Ockman, S.\& Stone, M.

1999 "Introduction" in DiBona et al. (eds.) Open Sources: Voices from the Open Source Revolution. Cambridge et al.: O'Reilly.

Fisher, J. H.

1993 "Copyright: The Glue of the System". Journal of Electronic Publishing 1, 15.
1997 "Comparing Electronic Journals to Print Journals: Are There Savings?" Andrew W. Mellon Foundation Conference "Scholarly Communication and Technology, 1997-04-24/25, Emory Univ.

Franks, J.

1993 What is an Electronic Journal? (Message to the Public-Access Computer Systems Forum <PACS-L $>$ in four parts); http:// listserv.uh.edu/cgi-bin/wa?A2=ind 9301c \&L=pacs- $1 \& \mathrm{P}=5953,6067,6181$, 6295.

Frisch, E.

1996 "Elektronische Fachzeitschriften im WWW als Paradigmenwechsel im System wissenschaftlichen Publizierens" (Electronic journals in the WWW as change of paradigm in the system of scientific publishing). Pp. 361-374 in Krause et al. (eds) Herausforderungen an die Informationswirtschaft. Proceedings ISI'96. Konstanz: UVK-Universitätsverlag.

Getz, M.

1997 "Electronic Publishing in Academia: An Economic Perspective". Andrew W. Mellon Foundation Conference "Scholarly Communication and Technology, 1997-04-24/25, Emory Univ.

Ginsparg, P.

1996 "Winners and Losers in the Global Research Village". UNESCO conference, session Scientist's View of Electronic Publishing and Issues Raised, 19-23 Feb 1996, Paris.

Götze, D.

1996 "Die Rolle des Verlags" (The role of the publisher). Pp. 68-72 in Börsenverein des Deutschen Buchhandels e.V. (ed.) Die unendliche Bibliothek, Verlag und Bibliothek. Wiesbaden: Harrassowitz.

Gräbe, H.-G.

1998 "Wissenschaft zwischen Freizügigkeit und Kommerz" (Science between freedom and commerce). 1998-06-12/13, Frankfurt am Main. http://www. informatik.uni-leipzig.de/ graebe/ projekte/infopapers/ffm.html. 
Graetzel von Graetz, P.

2000 "Ein Paradigmenwechsel in der Wissenschaftspublizistik" (A change of paradigm in scientific publishing). Telepolis 27.1.2000.

Grötschel, M. \& Lügger, J.

1996 "Neue Produkte für die digitale Bibliothek: die Rolle der Wissenschaften" (New products for the digital library: the role of the sciences). Pp. 38-67 in Börsenverein des Deutschen Buchhandels e.V. (ed.) Die unendliche Bibliothek. Verlag und Bibliothek. Wiesbaden: Harrassowitz.

Guernsey, L.

1998 "A Provost Challenges His Faculty to Keep Copyright on Journal Articles". The Chronicle of Higher Education, 1998-09-18.

Harnad, S.

1993 "Implementing Peer Review on the Net: Scientific Quality Control in Scholarly Electronic Journals". International Conference on Refereed Electronic Journals, 1993-10-01/02, Univ. of Manitoba, Winnipeg.

1997 "Learned Inquiry and the Net: The Role of Peer Review, Peer Commentary and Copyright”. Antiquity, 71: 1042-1048.

1998 "On-line journals and financial fire walls”. Nature 395, 9: 127-128. n.y. Copyright F.A.Q. (CogPrint Archive); Accessed on: 15.2. 2001. http://cogprints.soton. ac.uk/copyright.html.

Harnad, S., Varian, H. \& Parks, B.

2000 "Academic publishing in the online era what will be for-fee and what will be for-free?" Culture Machine, 2.

Hartmann, F.

2001 "Akademische OpenCulture oder globales WissensBusiness" (Academic open culture or global knowledge business). Telepolis, 10.5.2001.

Hibbitts, B. J.

1996a "Last Writes? Reassessing the Law Review in the Age of Cyberspace". New York University Law Review 71, June: 615-688.

1996b "Yesterday Once More: Skeptics, Scribes and the Demise of Law Reviews". Akron Law Review 30: 267.
Hunter, K.

1998 "Adding Value by Adding Links". Journal of Electronic Publishing 3, 3.

Jensen, $\mathrm{M}$.

1998 "Cost Recovery and Destiny: Developing the Appropriateness Matrix". Journal of Electronic Publishing 4, 1.

Johnston, C.

1998 "Electronic technology and its impact on libraries". Journal of Librarianship and Information Science 30, 1: 7-24.

MacKie-Mason, J. K. \& Riveros, J. F.

1997 "Economics and Electronic Access to Scholarly Information". Internet Publishing and Beyond: Economics of Digital Information and Intellectual Property, 1997-01-23/25, Cambridge, MA.

Morton, B.

1997 "Is the Journal as We Know It an Article of Faith? An Open Letter to the Faculty". The Public-Access Computer Systems Review 8, 2.Mueller, M.2000 The library catalog, the word processor, and the digital archive: Three stages of information technology in humanities scholarship. Accessed on: 10-23 2000. http:// faculty-web.at.nwu.edu/english / mmueller/ariadne/bibliography/ threestagesframe. htm.

Odlyzko, A. M.

1994 "Tragic Loss or Good Riddance? The Impending Demise of Traditional Scholarly Journals". Journal of Universal Computer Science 0, 0: 71-122 (quoted according to manuscript).

Okerson, A.

1991a "Back to Academia? The Case for American Universities to Publish Their Own Research". Logos 2, 2: 106-112.

1991b "The Electronic Journal: What, Whence, and When? [Paper delivered at the OCLC Users Council Annual Meeting in February 1991]". The Public-Access Computer Systems Review 2, 1: 524.

1997 "Midnight in the Garden of Good and Evil? Libraries, Academic Publishing, Copyright, and other Miasmas." http:/ / www.library.yale.edu/ okerson/ okerson-sf.html. 
Okerson, A. S. \& O’Donnell, J. J. (eds)

1995 Scholarly Journals at the Crossroads A Subversive proposal for Electronic Publishing: Association of Research Libraries.

Owen, J. M.

2000 "The New Dissemination of Knowledge: Digital Libraries and Institutional Roles in Scientific Publishing”. Workshop "The Economics of Scientific Publication" of the Erasmus Institute for Philosophy and Economics, April 19, 2000, Rotterdam.

Pew Higher Education Roundtable

1998 “To Publish and Perish”. Policy Perspectives 7,4 .

Raymond, E.

1999 “Die Kathedrale und der Basar" (The cathedral and the bazaar). LinuxMagazin: 132-145.

Roberts, R. J., Varmus, H. E., Ashburner, M., Brown, P. O., Eisen, M. B., Khosla, C., Kirschner, M., Nusse, R., Scott, M. and Wold, B.

2001 "Building A 'GenBank' of the Published Literature”. Science 291, 5512: 23182319.

Rohe, T. A

1998 "How Does Electronic Publishing Affect the Scholarly Communication Process?". Journal of Electronic Publishing 3,3 .

Rowen, L., Wong, G. K. S., Lane, R. P \&

Hood, L.

2000 "Publication Rights in the Era of Open Data Release Policies". Science 289, 2000-09-15: 1881.

Rowland, F.

1994 "Electronic Journals: Neither Free Nor Easy”. EJournal 4, 2.

Sietmann, R.

1999 "Zirkelspiele. Die wissenschaftliche Literaturversorgung steckt weltweit in der Krise" (Circle games. The supply of scientific literature is in crisis worldwide). c't 20: 216-231.

Taubes, G.

1996 "Electronic Preprints Point the Way to 'Authors Empowerment'”. Science 271, 1996- 02-09: 767-768.
Thatcher, S. G.

1996 "Re-engineering Scholarly Communication: A Role for University Presses?". Journal of Scholarly Publishing 27, 4: 197-207.

Tomlins, C. L.

1998 "The Wave of the Present: The Printed Scholarly Journal on the Edge of the Internet”. Journal of Scholarly Publishing 29, April: 133-150.

TRLN (Triangle Research Libraries Network)

1993 Model University Policy Regarding Faculty Publication in Scientific and Technical Scholarly Journals - A Background Paper and Review of the Issues; Last update: July 1993.

Ullman, J. D.

1996 "Research Publication Modes Need to be Reengineered. A discussion”. Computing Research News, July.

Walker, $\mathrm{N}$.

1995 "The University Press in the 21st Century". Journal of Scholarly Publishing $27,1: 37-42$

Walker, T. J.

1998 "Free Internet Access to Traditional Journals". American Scientist 86, 5.

Wasserman, $\mathrm{M}$.

1998 "How Much Does It Cost to Publish A Monograph and Why?" Journal of Electronic Publishing 4, 1.

Whisler, S. \& Rosenblatt, S. F.

1997 "The Library and the University Press: Two Views of the Costs and Problems of the Current System of Scholarly Publishing". Andrew W. Mellon Foundation Conference "Scholarly Communication and Technology", 1997-04-24/ 25, Emory Univ.

Wittenberg, $\mathrm{K}$

1998 "CIAO: A New Model for Scholarly Publishing". Journal of Electronic Publishing 3,4 .

Zeigler, J. F.

1997 "Gutenberg, the Scriptoria, and Websites”. Journal of Scholarly Publishing 29, October: 36-43.

Michael Nentwich

Institute of Technology Assessment (ITA)

Austria

mnent@oeaw.ac.at 